\title{
NOTES ON THE TRANSFORMATION OF THE EAST TIMOR MILITARY COMMAND AND ITS IMPLICATIONS FOR INDONESIA
}

Douglas Kammen

In early August, an editorial in the Jakarta Post about atrocities committed by the military in Aceh summed up much national sentiment in Indonesia in no uncertain terms.

As shocking as those revelations [from Aceh] may be, the use of excessive force on civilians by members of the Armed Forces is not actually new. To this day, the 1991 Santa Cruz incident in the East Timorese capital of Dili remains an indelible stain on the history of Indonesia's presence in the troubled province. ${ }^{2}$

From this lament about Indonesia's "presence" abroad, the editorial shifts to the domestic scene.

Similar force was applied during the July 27, 1996 riot in Jakarta which is still a hot topic for public debate. Most recently of course was the abduction and torture of young, dissenting political activists. In other words, [sic] the use of brutal and excessive force on citizens of this country, during peacetime, by members of their own Armed Forces intent on achieving political objectives.

The editorial concludes:

${ }^{1}$ I would like to thank Ben Anderson, David Bourchier, Michael Malley, Made Tony Supriatma, and John Sidel for incisive comments on a draft of this paper.

2 "The Aceh Killing Fields," Jakarta Post, August 7, 1998. 
62 Douglas Kammen

Tragically this has become common practice in the country over the years. It is difficult to say exactly when this penchant for killing and torturing their own people began .... But while it is hard to say when it all began, it is easy to say when it must end: immediately.

In themselves, of course, kidnappings, the instigation of riots, organized rapes, and state-sponsored murders are not new to the Soeharto era. But these tactics have traditionally been reserved for "trouble" areas-East Timor, Aceh, Irian Jaya-or for what the regime considered to be "troublesome" (or simply expendable) groups-the 1974 student demonstrators, the petty criminals targeted in the "petrus" killings 1983, etc. The increasingly frequent use of violence as an administrative tool in Java during the mid-1990s marked a significant new development in Soeharto's Indonesia.

The ambition for most people in 1998 was to identify the parties responsible and demand that they be punished accordingly. In August 1998 this ambition was partially satisfied when Lieut. Gen. Prabowo Subianto, son-in-law of General (Ret.) Soeharto and commander of the much-feared Special Forces (Kopassus), testified in front of a Military Honor Board that he organized and carried out the spree of kidnappings and disappearances, though claiming that he did so on orders from his superiors. ${ }^{3}$ On August 24, 1998 Lieut. Gen. Prabowo was discharged from the Armed Forces, two other Kopassus officers were relieved of all military duties, and soon thereafter eleven lower-level Kopassus personnel were placed on trial. ${ }^{4}$

In this essay I would like to address the question raised by the Jakarta Post. Rather than asking who "masterminded" the kidnappings, murders, riots and rapes in 1998, I propose to ask when and why terror came to be used by particular ABRI officers and units as an administrative method against civilians in Indonesia. I will argue that one important lineage line connecting the forms and uses of violence that contributed to Soeharto's resignation in May 1998 can be traced back to changes in the military occupation of East Timor. ${ }^{5}$ Although often cosmetic in nature, taken together these changes had significant implications for the Indonesian military, and it is here that we must look to understand the escalating use of terror and violence by particular segments of the military during the 1990s against Indonesian citizens in non-"trouble" areas.

\section{The Dual Structure of the Timor Command}

During the 1980s the Indonesian military employed a dual structure in East Timor-one part "combat," one part "territorial." Combat operations in the former Portugese colony were carried out by the Operations Implementation Command

\footnotetext{
3 "Prabowo Mengaku Diperintah Atasan," Suara Merdeka, August 11, 1998. The culpability of Prabowo's superiors is an issue beyond the scope of this essay.

4 "Prabowo Dipecat," Suara Pembaruan, August 24, 1998. See also Siapa Dalang Prabowo (Jakarta: Tim Pemburu Fakta, 1998).

${ }^{5}$ There are, of course, other lineages, some of which are addressed in this and the previous issue of Indonesia.
} 
(Komando Pelaksana Operasi, Kolakops), 6 headed by a brigadier general, under whom served two colonels directly responsible for the military operations areas known as "Sector A" (the eastern half of East Timor) and "Sector B" (the western half of East Timor). ${ }^{7}$ This command coordinated day-to-day planning and logistics, combat activities, and the massive forced relocations of the local population. ${ }^{8}$

In 1979, four years after the Indonesian invasion, ABRI established a Sub-regional Military Command (Korem) in East Timor. Based in Dili, Korem 164 oversaw the operations of the thirteen District Military Commands (Kodim) and sixty-one Subdistrict Military Commands (Koramil). ${ }^{9}$ This was essentially the same so-called "territorial" structure as in the forty Korem that cover Indonesia's twenty-six provinces. Indeed, the establishment of Korem 164 in East Timor was originally intended not for the purpose of security, a role already carried out by the Kolakops combat command, but rather to support Jakarta's claim that East Timor was administered like, and therefore no different than, the other provinces in Indonesia.

There are, however, two features of the Korem structure in East Timor that distinguished it from those elsewhere. First, while Korem are commanded by an officer with the rank of colonel, who is then assisted by a chief of staff (with the rank of lieutenant colonel), Korem 164 in East Timor had both a chief of staff and a deputy Korem commander (both with the rank of lieutenant colonel). This doubling was adopted in order to mirror the division of the operational command into sectors $A$ and B. These two officers ensured that territorial units under Korem 164 provide the necessary support and logistical back-up for Kolakops operations. The second peculiarity of the territorial command in East Timor is the number of "organic" [i.e. locally based] battalions. Whereas Korem in Indonesia normally oversee only one territorial infantry battalion, Korem 164 has two such territorial battalions under its command: Infantry Battalion 744/Satya Yudha Bhakti, based in Dili, and Infantry Battalion 745/Sampada Yudha Bhakti, based in Los Palos. Again, the doubling in numbers corresponds to the two "combat" sectors.

Throughout the 1980s the relationship between the combat and territorial commands in East Timor was clear: Kolakops ran the war and occupation, Korem 164 provided auxiliary support and the fiction of normalcy. Relative positions within this hierarchy were underscored by the ranks of the respective commanding officers. The Kolakops commander, a brigadier general, was senior to the colonel who headed

${ }^{6}$ The original command established in 1976 was called the Defense Security Command (Komando Pertahanan Keamanan); in 1984 this became the Security Operations Command (Komando Operasi Keamanan). The last incarnation, Kolakops, was formally established in 1989.

7 During the 1980s the capital city Dili comprised a third "Sector C"; this was abolished sometime after the November 1991 Santa Cruz massacre, at which point Dili was incorporated in Sector B. See "Operasi Teritorial ABRI Melawan Fretilin Mendekati Rakyat," Forum Keadilan, September 25, 1995, p. 51.

${ }^{8}$ See the remarkable commemorative volume Kolakops Timor Timur Dalam Gambar Dan Peristiwa Tahun 1992-93 (Dili: no publisher, 1993), p. 3.

${ }^{9}$ This is a far greater number of Kodim per geographic area than is found anywhere in Indonesia, an issue recently raised by members of the Indonesian Human Rights Commission (Komnas HAM). See "Komnas Sambut Baik Rencana Perampingan Aparatur Negara," Kompas, February 4, 1998. 
Korem $164 .^{10}$ This relationship, however, had a curious flip-side. The commissioned officers in the Kolakops command and the troops sent out on combat missions served relatively brief tours in East Timor (normally from nine to twelve months). By contrast, Korem 164 was staffed largely by non-commissioned officers or officers who knew that they would not be promoted any higher within the military and who could therefore look forward to the prospects of long postings in distant Timor. ${ }^{11}$

This distinction between combat and territorial responsibilities is reflected in the growth of business interests in East Timor. The closed nature of the province facilitated the rise of military and palace business monopolies in various commodities (coffee, sandalwood, etc.) and import-export. Indeed, East Timor was run as a virtual appanage granted by Soeharto to family members and loyal subordinates. Over time this commercial modus operandi was paralleled by the emergence of business interests in the territorial command: staff officers suffering career stagnation engaged in side-line enterprises to supplement their meagre salaries and situate themselves for retirement. ${ }^{12}$ These "rackets" and local political ambitions were, of course, facilitated by the closed nature of East Timor and the dependence of the Kolakops combat command and generals in Jakarta on the cooperation of these local personnel.

The decision in December 1989 to open East Timor had an immediate and dramatic impact on military rule. In 1989, as part of the military's so-called "Operation Smile" (Operasi Senyum), Kolakops began to tighten military discipline and to grant greater freedom to civilians. ${ }^{13}$ In the words of the editors of the journal Indonesia:

It is rather clear that one of the missions of the popular Menadonese Commander, Brig. Gen. Rudolf Samuel Warouw, when he took office in December 1989 . . . was to clear up the conduct of the entrenched local military mafia. During his two years in office, over three hundred military personnel were "disciplined" in various ways and for various abuses-a policy line which naturally made him unpopular with many of his subordinates and encouraged plotting against him ... 14

This, the editors of Indonesia argued, was a primary factor behind the Santa Cruz massacre in 1991. Threatened by Warouw's disciplinary campaign, military personnel opened fire on the peaceful procession in the Santa Cruz cemetary in order to discredit both Warouw and the sympathetic Governor Mario Carrascalao, whose second term in office was nearing completion.

${ }^{10}$ During the 1980 s and early 1990 s the hierarchical relationship between the two units was even more direct: the commander of Korem 164 simultaneously served as the deputy commander of Kolakops. See, for example, George Aditjondro, "ABRI Inc.," Sydney Morning Herald, May 8, 1999.

11 One striking piece of evidence in support of this theory is the fact that prior to the Dili massacre a majority of staff and personnel in Korem 164 were non-Akabri (military academy) graduates, for whom career opportunities are quite limited. Since then there has been a shift towards the appointment of Akabri graduates who have far better formal education and, as a result, superior career prospects.

12 This point is made by Editors, "Current Data on the Indonesian Military Elite: July 1, 1989-January 1, 1992," Indonesia 53 (April 1992): 98.

${ }^{13}$ See, for example, "Tak Akan Sesabar Warouw," Editor, January 18, 1992.

${ }^{14}$ Editors, "Current Data," Indonesia 53, p. 98. 
The intra-military tensions resulting from Operasi Senyum were accompanied by two additional developments. First, the "opening" of East Timor involved altering the relationship between the combat and territorial military commands. Heightened foreign scrutiny of Indonesian rule in the province meant that "combat" units and officers would need to play a less conspicuous (though no less effective) role. Similarly, attempts to encourage new business in East Timor would require assuring capital of the safety of investments, something best achieved by emphasizing "territorial" administration rather than "combat" operations. Together, these needs prompted a shift in the military structure in East Timor from the purely combat command of Kolakops to the "territorial" command of Korem 164.

This change in the structure of the Timor command raises important questions about what Col. Warouw was doing and to whom. The Editors of Indonesia argue that Warouw began his clean-up campaign "when he took office in 1989."15 This is correct but also misleading. Warouw was appointed as commander of Korem 164 in April 1989 and held the position for one year. During this time Warouw could take disciplinary measures against personnel in the "territorial" Korem 164, but had no direct authority over the staff or troops under Kolakops. In May 1990, Warouw was transferred to command Kolakops. It was only at that point, when Warouw began to address irregularities in the operation of combat troops in East Timor-who were engaged in the most brutal abuses-that outright resistance to the new commander and command structure emerged within the military.

This brings us to the second dynamic at work in the months prior to the Dili massacre. One of the units that played a regular role in the Timor campaign during the 1980s was the Kostrad 3rd Airborne Brigade (Brigif Linud 3), conveniently based in Maros, South Sulawesi, an hour's flight from Dili. The peculiar feature of Brigif Linud 3 was that during the late 1980 s it operated independently of the two Java-based Kostrad Infantry Divisions, reporting directly to the Kostrad commander-in-chief. ${ }^{16}$ This, of course, permitted Brigif Linud 3 unusual freedom from immediate supervision. In April, 1991, as part of the overall shift of administrative emphasis in East Timor from Kolakops to Korem 164, Brigif Linud 3 was moved directly under the command of the West Java-based Kostrad First Infantry Division. ${ }^{17}$ This reorganization was

\footnotetext{
${ }^{15}$ Ibid. To date there is (to my knowledge) no complete biographical sketch of Warouw. It is useful to note that he was the second member of his graduating class from the National Military Academy (AMN 6 1965) to be appointed as a Korem commander, a prestigious step in the career of a middle-ranking officer.

16 The history of Brigif Linud 3 is worth noting. Special Forces Group 3 (Group 3 Kopassandha) was established in 1963 from troops that had participated in the campaign to "liberate" West Irian from Dutch control. In 1985, as part of Gen. Moerdani's reorganization of the military, Group 3 Kopassandha became Special Forces Airborne Infantry Brigade 3 (Brigif Linud 3 Kopassus); the following year it was transferred from Kopassus to Kostrad. It seems likely that Prabowo's early service in East Timor in the late-1970s and early 1980s was as part of Group 3 Kopassandha, and that these links remained central to his vision of the Timor campaign. In a 1996 interview about Kopassus under his command, Prabowo commented "at the moment the dormitory [asrama] in Ujung Pandang belongs to Kostrad." Although Brigade3 had been transferred to Kostrad more than a decade earlier, Prabowo's comment suggests that he viewed this as a temporary state of affairs. See "Brigjen TNI Prabowo Subianto: Ada Kelompok Yang Mau HuruHara," Tiras, July 14, 1996.

17 "HUT Ke-31 Divisi Infanteri I Kostrad: Dari Irian Barat, Menjaga Zaman . . ", Kompas, December 26, 1996.
} 
intended to provide greater coordination between combat units stationed in Timor and to prevent officers and units from acting outside of the chain of command.

\section{Identifying the Butchers of Dili}

Despite the military's attempted cover-up, we are fortunate to have detailed information about the battalions on duty in East Timor at the time of the Santa Cruz massacre. What is clear is that in late 1991 Kostrad was extremely well represented in East Timor. The commander of Brigif Linud 3, Col. (Inf.) Moch. Thamrin, was serving concurrently as commander of operations Sector C, covering the capital city Dili. ${ }^{18}$ At least three other Kostrad battalions were posted in East Timor as well: Yonif 433 (which is part of Brigif Linud 3, based in Maros, South Sulawesi), ${ }^{19}$ Yonif 303 (part of Brigif Linud 17, based in Cijantung, Jakarta), ${ }^{20}$ and Yonif 411 (which is part of Brigif 6 , Central Java). ${ }^{21}$ In addition, Airborne Infantry Battalion 700 , based in South Sulawesi, was operating in East Timor, as were three "territorial" battalions from West Java. ${ }^{22}$

Table 1

Troops in East Timor at the time of the Dili massacre, November 1991

\begin{tabular}{llll}
\hline Battalion & Service Branch & \multicolumn{1}{c}{ Base } & $\begin{array}{c}\text { Dates known to be } \\
\text { in E. Timor }\end{array}$ \\
\hline Yonif 303 & Kostrad & Cikajang, West Java & Nov. 1991 \\
Yonif 411 & Kostrad & Central Java & $?-14.2 .92$ \\
Yonif 433 & Kostrad & Maros, S. Sulawesi & $9.91-1.93$ \\
Yonif 700 & Kodam VII & Maros, S. Sulawesi & Nov. 1991 \\
Yonif 312 & Kodam III & Subang, West Java & $?-8.1 .92$ \\
Yonif 315 & Kodam III & Borgor, West Java & $1991-1992$ \\
Yonif 320 & Kodam III & Serang, West Java & $?-6.2 .92$
\end{tabular}

Taken together, a picture emerges of Kostrad units operating in Dili in late 1991 which shared several common traits: all had served frequent tours in East Timor; all had recently come under greater control of Kostrad headquarters and the infantry division commanders; and all were facing increased disciplinary action by the new Kolakops commander in East Timor.

${ }^{18}$ Reported in the feature series "Kapal Politik Portugal," Editor, March 14, 1992. According to the Kolakops volume, Col. M. Thamrin was replaced as commander of Sector B in mid-March, 1992, suggesting that he may have commanded both Sectors B and C at the time of the massacre. See Kolakops, p. 181.

19 See "Mengenal sejarah singkat: Brigif Linud 3/Tri Budi Maha Sakti," Angkatan Bersenjata, December 12,1995 . Tempo reported that these units were in the "jungle" when the Santa Cruz massacre occurred, though this seems unlikely given that their commander was in charge of Dili. See "Peristiwa itu Tak Jatuh dari Langit," Tempo, December 7, 1991.

20 Reported in "Laporan KPN dan Sikap Kesatria," Editor, January 4, 1992, pp. 18-19.

21 Kolakops, p. 181, reports that Yonif 411 Kostrad left East Timor in February, 1992. Editor, January 4, 1992, reports that Yonif 413 Kostrad (also from Brigif 6) was in East Timor as well, though it is unlikely that two battalions from the same brigade were on combat duty simultaneously. I suspect that this article has mistaken the battalion numbers.

22 Given the geographic proximity of their bases in South Sulawesi, it is likely that Yonif Linud 700 was operating under the command of Brigif Linud 3. 
Postings of Officers Involved in Santa Cruz Massacre

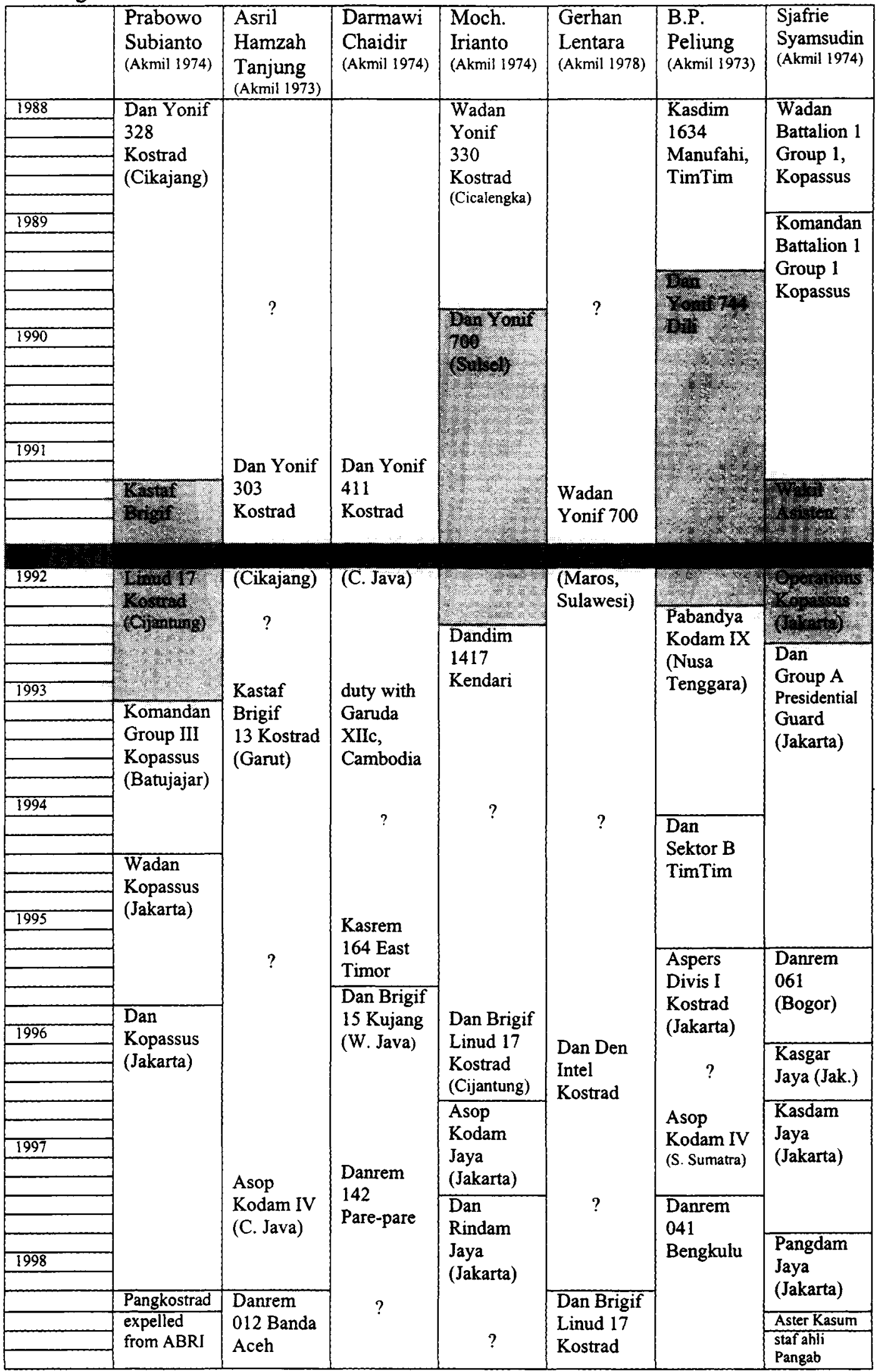


68 Douglas Kammen

Of course the decision to open fire on unarmed demonstrators trapped within the Santa Cruz cemetary was made by individuals, not battalions. Several officers are known to have been in East Timor immediately prior to the November 11 massacre, and it is to these figures that we must look to understand the origins and logistics of the massacre. The first of these officers was Lieut. Col. Prabowo Subianto, brash son of economist Prof. Sumitro Djojohadikusumo and son-in-law of President Soeharto. A 1974 graduate of the military academy, Prabowo spent much of his murderous early career in East Timor. ${ }^{23}$ In 1991 Prabowo was the chief of staff of the Kostrad 17th Airborne Infantry Brigade, based in Cijantung, Jakarta, a unit that was not on official assignment in East Timor. Despite his posting far from occupied Timor, Prabowo remained active in Dili. According to one source: "For Prabowo, Tim Tim [East Timor] was like home. He was often in Tim Tim without the knowledge of his superiors." 24 In late October 1991, prior to the October 28 shooting of two Timorese in the Motael Church, Prabowo was often seen in the streets of Dili. One Timorese activist explains: "But in the days before November 12, 1991, when the Santa Cruz affair exploded, Prabowo wasn't visible in Dili. He seemed to disappear. But afterwards, when UN special envoy Amos Wako visited East Timor to investigate the victims of the Santa Cruz massacre, Prabowo reappeared."25

The second key figure in Dili at the time was Lieut. Col. Sjafrie Syamsudin, a classmate and close friend of Prabowo. In 1989-90, while posted as commander of Kopassus paracommando Battalion 1, Group 1 in Serang, West Java, Sjafrie participated in (commanded?) a Kopassus Task Force (Satgas Kopassus) in East Timor. ${ }^{26}$ In September, 1991, Sjafrie was posted as the Special Forces deputy assistant for operations in Jakarta. According to sources in East Timor, in the days before the November 11 massacre Sjafrie visited the Kopassus Intelligence Task Force (Satuan Tugas Intelijen, SGI) in Taibesi to "coordinate troops."27 Taibesi, of course, is also home of Yonif 744, one of the battalions known to have been involved in the massacre on November 11. Just as Prabowo "disappeared" from public view in the days prior to the massacre, on November 10, 1991, Sjafrie left Dili.

There can be little doubt about the central role played by Lieut. Cols. Prabowo Subianto and Sjafrie Syamsudin in the Dili massacre. Both have extensive combat records in East Timor; both were in Timor immediately prior to the massacre; and the two are classmates and close friends. After a recent lecture, Gen. (Ret.) Theo Sjafei,

23 Official biographies carefully gloss over the early stage of Prabowo's career. For a partial explanation, see footnote 15 .

24 I am grateful to $M$. for this information.

25 Ibid.

26 Biographical information provided in "Lebih Jauh Dengan Mayjen TNI Sjafri Sjamsoeddin," Kompas, March 1, 1998. During this period the military carried out a brief campaign intended to "capture Fretilin President Xanana Gusmao" and prevent popular protest on the occasion of the Pope's visit. In the words of one Timorese activist: "In order to cow and intimidate the population in advance of the Pope's visit, numerous Timorese were rounded up, imprisoned and tortured. Lieutenant-Colonel Prabowo, President Soeharto's son-in-law, at that time serving in East Timor, personally tortured [my friend] Idelfonso Araujo, breaking his leg and his teeth." See Gomes, "The East Timor Intifada," in East Timor at the Crossroads, ed. Peter Carey (Honolulu: University of Hawaii Press, 1995), p. 107.

${ }^{27}$ It is not known if this is the same task force that Sjafrie commanded in 1989-90. 
who served as Kolakops commander in 1992-1993, identified the masterminds of the Santa Cruz massacre in no uncertain terms:

I have to say to you that yes, [the Santa Cruz massacre] was orchestrated. It was orchestrated by the two parties, by them [Fretilin] and by us [ABRI]. And [commander of Korem 164] Rudy Warouw didn't know about the scheme because it was carried out by a commander . . . below Rudy Warouw. That commander in fact is named Syafri . . . 28

Sjafrie, of course, was not acting alone.

From here, it remains to sketch the personal and operational links between these two officers and the four key units on duty in Timor at the time. (See Table 1) Yonif $303 \mathrm{Kostrad}$, one of the units publicly implicated after the massacre, is a sister unit to Yonif 328, which was commanded by Prabowo from 1988 until early 1991; cooperation came naturally between officers and troops who had worked together for several years. While it is unlikely that Col. Moch Thamrin, commander of Brigif Linud 3, was personally involved in the Santa Cruz massacre, Prabowo's long-standing association with Brigif Linud 3 (see footnote 14) clearly facilitated the participation of Yonif 433. The commanders of Yonif 411, Lieut. Col. Darmawi Chaidir, and Yonif 700, Lieut. Col. Moch. Irianto, were both 1974 classmates of Prabowo and Sjafrie, while the deputy commander of Yonif 700, Mayor Inf. Gerhan Lentara, has a long history of serving under Prabowo in East Timor. ${ }^{29}$ Lastly, Yonif 744, which was visited by Sjafrie the night before the massacre, was commanded by Mayor Inf. B. P. Peliung, an officer with extensive Timor service who, presumably, had previously worked with both of the masterminds.

Additional insights into the troops responsible for the Dili massacre can be adduced from the military response in the following months. In the face of domestic and international outrage, Soeharto ordered the summary and highly publicized sacking of both Kodam IX Udayana commander Maj. Gen. Sintong Panjaitan and Kolakops commander Colonel Warouw. In addition, a Military Honor Board (Dewan Kehormatan Militer) was established to investigate the causes of the massacre. ${ }^{30}$ The purge was not limited to senior ranks, however. The commanders of Kostrad First Infantry Division and the brigades (Brigif Linud 3, Brigif 13 and, by all appearances, Brigif Linud 17) immediately responsible for the troops on duty in Timor in November 1991 virtually disappeared from sight. ${ }^{31}$ By contrast, the battalion commanders (most of whom were lieutenant colonels) on duty in East Timor at the time and most immediately involved in the massacre and crackdown all fared quite well since 1991.

\footnotetext{
28 Question and answer period following a lecture at the Forum Bakti Kasih Kristiani, June 8-9, 1998.

29 See, for example, "Current Data," Indonesia 53, p. 103.

30 Ibid., p. 99.

31 At the time, the commander of the Kostrad First Infantry Division, Ilyas Yusuf, was a rising star with extensive combat duty and tours of duty as commander in key middle-level territorial units; he has since been sidetracked into administrative and educational fields, serving as Governor of the Military Academy (Akabri) and Coordinator for Expert Staff to the Army Chief of Staff. Similarly, the commander of Brigif Linud 3, Col. (Inf.) Moch. Thamrin, also disappeared from public view. Given that command of the Kostrad infantry brigades is normally a sign of a fast-track career, the fate of these officers reveals that the purge was not limited to the senior ranks alone, and it provides strong evidence that the officers and/or units from the Kostrad First Infantry Division were held responsible for the Dili massacre.
} 
70 Douglas Kammen

Despite their immediate involvement, Prabowo, Sjafrie and friends continued to rise in the military because of their palace connections; their superiors were side-tracked and eventually retired because of what they knew.

\section{Restructuring the Timor Command}

In the wake of the Dili massacre and resulting personnel reshuffles, ABRI surely but quietly carried out a wholesale reorganization of the East Timor command. The first step in this process was initiated in January 1992, when Brig. Gen. Theo Sjafei replaced Brig. Gen. Warouw as head of Kolakops and Col. Dunidja D. replaced Col. J. P. Sepang as commander of Korem 164 . Theo Sjafei wasted no time in making his stance towards the Timorese population clear, explaining "if something similar to the 12th November event were to happen under my leadership, the number of victims would probably be higher." 32

Over the next several months sweeping personnel changes were carried out in the Kolakops command. Between January and March most of the Kolakops assistants were replaced. ${ }^{33}$ This paved the way for a further military operation-called Operasi Tuntas (Operation Completion)-which, in contrast with past practice, was expressly termed "territorial" rather than "combat." In the words of the military, this operation aimed "to improve living conditions, enforce the law, protect religious freedoms, assist development programs" and, as if an afterthought, "to destroy the GPK [lit. "the movement to disrupt security", i.e. Falintel] and its supporters." 34

During this same period new officers were installed to command the two Kolakops combat sectors. Some time soon after the Dili massacre Lieut. Col. Slamet Kirbiantoro was appointed commander of Sector A (the eastern part of East Timor). ${ }^{35}$ In March 1992, Col. Thomas Albert Umboh was appointed commander of Sector B (covering the western part of East Timor and, following the abolition of Sector C, the capital of Dili as well); seven months later he was replaced by Lieut. Col. Djamari Chaniago. Significantly, these new appointees held dual commands, with posts in both Kostrad and the Timor command. In September 1992, newly promoted Col. Kirbiantoro, who continued to hold his post as commander of Sector A, was simultaneously appointed to command Brigif. Linud 3 in South Sulawesi, at least one of whose battalions was deeply involved in the Dili massacre. ${ }^{36}$ Similarly, Lieut. Col. Djamari Chaniago simultaneously served as commander of Kostrad's 18th Airborne Infantry Brigade,

32 Quoted in Carey, East Timor at the Crossroads, p. 248.

33 Many of these moves are reported in "Rangkaian Mutasi di Dili," Tempo, January 11, 1992, "Pergantian Komando dan Temuan," Editor, January 18, 1992 and "Serah Terima 5 Jabatan di Kolakops Timtim," Angkatan Bersenjata, March 21, 1992.

34 Kolakops, p. 22. Falintel = Forcas Armadas de Libertacao Nacional de Timor-Leste.

35 Unfortunately there are no reports of Kirbiantoro's appointment or previous post. Given that this is not listed in the exhaustive January 1992-March 1993 chronology in the Kolakops commemorative volume, I assume that Kirbiantoro was appointed sometime in December, 1991.

36 The official career biographies distributed by ABRI to the media at the time of personnel changes all omit mention of service as commander of Sectors A and B. The evidence for Kirbiantoro is reported in Angkatan Bersenjata, September 3, 1992 and Kolakops, p. 70. 
based in Malang, East Java. ${ }^{37}$ Both Brigif Linud 3 and Brigif Linud 18 have long-time East Timor experience and both continued to play a central role in the territory after the abolition of Kolakops. ${ }^{38}$ By all appearances, then, the command and deployment of troops in the Timor campaign was being shifted out of East Timor to the Kostrad brigades, the commanders of which were taking on greater authority and responsibility for combat operations.

The transfer of direct military operations to particular Kostrad brigades paved the way for the next step in the restructuring of the Timor command. On April 30, 1993, Kolakops was formally liquidated and its responsibilities were handed over to Korem 164. At the time, Kolakops commander Brig. Gen. Theo Sjafei explained that the "simplification of the military organization in East Timor is a sign of greater stability and security." ${ }^{\prime 39}$ Were the military truly to abolish Kolakops, combat Sectors A and B and their respective commanders would also have been abolished. This did not occur, however. Both Col. Slamet Kirbiantoro and Col. Djamari Chaniago retained their posts well after the abolition of Kolakops. In other words, the liquidation of the Kolakops command in East Timor was a purely cosmetic act: the sectoral structure and commanders of Timor operations remained.

Following the formal abolition of Kolakops in April 1993, officers responsible for the East Timor territorial command made a series of public statements about the possibility of withdrawing troops from East Timor. In October 1993, the number of Kostrad battalions was in fact reduced, the commander of Korem 164 again citing the stability of the region as a reason. ${ }^{40}$ By early 1994 the formal shift from the expressly combat-oriented Kolakops command to a "territorial" Korem structure was nearly complete, with seven territorial battalions and only one Kostrad battalion stationed in East Timor. ${ }^{41}$ These changes represent a curious combination of structural change and deception: on the one hand Kolakops was liquidated, the number of combat battalions reduced, and formal authority handed to Korem 164; on the other hand the sectoral command structure remained unchanged, as did the total number of battalions and the overall level of troop deployment in the province.

\section{Batujajar}

Meanwhile, more sinister changes were taking place away from East Timor. In February 1993, Col. Prabowo was transferred from his post as Chief of Staff of Brigif

37 "Djamari Chaniago, Perwira yang Jarang Bicara," Republika, April 5, 1998 provides a rough, though incomplete, biographical sketch.

${ }^{38}$ For a detailed account of Brigif Linud 3's extensive combat service in East Timor, see "Mengenal sejarah singkat: Brigif Linud 3/Tri Budi Maha Sakti," Angkatan Bersenjata, December 12, 1995. At the time of Chaniago's appointment as commander of Sector B in October 1992, troops from Kostrad Battalion 501, under the command of Brigif Linud 18, were posted to East Timor. See "Yon 501 dan 507 Kostrad Ditarik Dari Timtim," Kompas, October 18, 1993.

39 Paraphrased in "Kolakops Timtim segera dibubarkan," Angkatan Bersenjata, March 16, 1993.

40 "Yon 501 dan 507 Kostrad Ditarik dari Timtim," Kompas, October 18, 1993.

41 "Tugas utama ABRI di Timtim 'Civic Mission'," Angkatan Bersenjata, March 2, 1994. A month later the number of battalions was reduced further. See "Tujuh Batalyon di Timtim dapat ditarik sesuai kondisi," Angkatan Bersenjata, April 16, 1994. 
Linud 17 Kostrad (which, it must be recalled, he had held since the Dili massacre) to command Kopassus Group 3, the Special Forces Education Center located in Batujajar, West Java. ${ }^{42}$ Based in the hills of West Java, and thus safely out of the direct public view, Prabowo was in an excellent position to oversee the training of Special Forces troops for use in Timor and, increasingly, also in the military operations areas in Aceh and Irian Jaya. ${ }^{43}$ These training efforts, of course, were greatly aided by the United States military and its longstanding support for the Soeharto regime. In the words of Allan Nairn:

By far the main recipient of the special US training has been a force legendary for specializing in torture, disappearances, and night raids on civilian homes. Of the twenty-eight Army/Air Force exercises known to have been conducted since 1992, Pentagon documents indicate that twenty have involved the dreaded KOPASSUS Red Berets. ${ }^{44}$

Indeed, Group 3 quickly became the new nerve-center of the Timor campaign, a campaign that was losing even the most rudimentary trappings of a combat mission and taking on the characteristics of a simple reign of terror conducted by professional killers.

It is necessary to underline the fact that Kopassus Group 3 in Batujajar became the informal center for Timor operations (or at the very least that part of the Timor operation overseen by Prabowo outside of the military's normal chain of command). Although it has not been possible to identify all of the officers who have commanded Kopassus Group 3,45 the available data unequivocally reveal the relationship between Group 3 and the Timor command. In 1996, Col. Harry Pisand Pinem served as commander of Group 3, after which he was appointed to command Sector A in East Timor, ${ }^{46}$ and the outgoing commander of Sector A, Col. Suhartono Suratman, then took up Pinem's post as commander of Group 3 in West Java. ${ }^{47}$ Such a direct exchange of posts between two officers is extremely rare in the Indonesian military and was certainly not a coincidence. This was done so as to maintain the control of Group 3 in particular and Kopassus in general over the Timor campaign. The control of Kopassus over East Timor was further strengthened by the simultaneous appointment of the former commander of Kopassus Group II (Col. Inf. Slamet Sidabutar), based in Kartasura, Central Java, to command Korem 164 in Dili. ${ }^{48}$

\footnotetext{
42 As the group number implies, this was a reincarnation of Kopassandha Group 3, based in Maros, South Sulawesi, which was later transferred to Kostrad, and in which Prabowo served during his early career.

43 The Red Net Military Operations Command (Kolakops Jaring Merah) was formally established in Aceh in 1989. See Serambi, July 14, 1997. Similarly, sometime in 1996 military operations sectors (known as E, F, and G) were established in Irian Jaya. These are identified in Angkatan Bersenjata, January 1, 1997 and Suara Pembaruan, August 29, 1998.

44 Allan Nairn, "Indonesia's Killers," The Nation, March 30, 1998, pp. 6-7.

45 There is a gap in 1995-96 (between the commands of Prabowo and Harry Pisand Pinem) for which no commander can be identified.

46 For these dates and posts see, for example, Jawa Pos, June 26, 1996 and Suara Timor Timur, January 15, 1997.

47 See Suara Timor Timur, February 2, 1996 and April 17, 1996; and Kompas, March 6, 1998.

48 With the death of the commander of Korem 164 in a helicopter crash in early June, 1998, Col. Suhartono Suratman, who was still commander of Group 3, was the natural choice to take fill the vacancy. Thus, even
} 
Meanwhile, two further changes were underway in the deployment of personnel to the occupied territory. During the mid-1990s many of the officers who were involved in the Dili massacre were assigned to new positions back in East Timor. There can be little doubt that Prabowo's political connections and rising influence in the military were central to this process. In April, 1994, for example, yet another pair of officers was installed to head combat sectors A and B. The new commander of Sector B was Col. Syahrial B. P. Peliung who, at the time of the Dili massacre was commander of Yonif $744 .{ }^{49}$ The new commander of Sector A was Col. Ryacudu Ryamizard, son-inlaw of Vice President Try Sutrisno and classmate and close friend of Prabowo. ${ }^{50}$ Shortly thereafter, Lieut. Col. Darmawi Chaidir, who had commanded Yonif 411 in East Timor in 1991, was appointed deputy chief of staff of Korem 164. ${ }^{51}$ Similarly, Lieut. Col. Moch. Irianto, who had served as commander of Yonif 700 in 1991, was promoted to command Kostrad Brigif 17, which sent troops to East Timor during the mid-1990s.52 (A number of the other officers known to have been in East Timor in late 1991 "disappeared" from public view during the 1994-1996 period, and it seems likely that they were posted in Kopassus or East Timor.) Thus, while ABRI claimed to have abolished Kolakops and to be ending combat operations in East Timor, it proceeded to appoint the very officers involved in the 1991 massacre to command the territory. In other words, the butchers of Dili were placed in charge of what had become a phantom combat command.

It is equally instructive to consider the deployment of battalions to the annexed territory. During the 1980s and early 1990s Kostrad provided the bulk of the troops stationed in East Timor. Following the abolition of Kolakops, these explicitly combatoriented units disappeared from public view and were replaced by "territorial" troops (those under the direct command of the ten regional and thirty-nine sub-regional commands) with what the military euphemistically called a "civic mission." But if territorial units were to take the lead in the East Timor occupation, it would be necessary to supplement their numbers and, perhaps also, to free them from responsibilities in their base areas. To this end, in 1994 the long-defunct 15th "Cleaver" Infantry Brigade (Brigif 15 Kujang) was reactivated under the command of Kodam III Siliwangi (West Java). ${ }^{53}$ The choice of location-Bandung, West Java-was not accidental: as close as possible to the Timor headquarters of Kopassus Group 3. Senior military officials did not provide an explanation for the re-establishment of the Brigif 15, and indeed it would be hard to justify the addition of another full brigade in a province which already boasted three territorial infantry battalions (under Kodam III

after Lieut. Gen. Prabowo's fall from grace in May, 1998, Kopassus retained a tight grip over East Timor. It is via these channels that arms are currently flowing to anti-independence paramilitary groups in Timor.

49 See Editors, "Current Data," Indonesia 53, p. 99 and "Dan Yonifter 744/SBY," Angkatan Bersenjata, May 12, 1992.

${ }^{50}$ In November 1991, Ryamizard was commander of Infantry Battalion 305 (based in Karawang), under Brigade Linud 17 Kostrad, of which Prabowo was then chief of staff.

${ }^{51}$ Reported in Angkatan Bersenjata, January 31, 1995.

52 See Pikiran Rakyat, May 9, 1998.

53 The 15th Infantry Brigade was originally a combat (as opposed to territorial) unit and served in a number of military campaigns during the 1960s. This new brigade was comprised of the 310th Infantry Battalion based in Sukabumi, the 312th Infantry Battalion in Subang, and the sinisterly named "Hunting Team" (Tim Pemburu) 327th Infantry Battalion in Bandung. 
Siliwangi) as well as two Kostrad brigades. The Armed Forces daily did note, however, that Brigif 15 was "reactivated . . . in order to anticipate challenges and new contingencies in the [West Java] region." 54 Both Yonif 312 and Yonif 327 served in East Timor during the mid-1990s, the former taking credit for the murder of Falintil (Forcas Armadas de Libertacao Nacional de Timor-Leste) leader David Alex in 1997.55

But perhaps the most important change in personnel deployment in East Timor does not involve regular troops but rather the use of "non-regulars." 56 The administrative use of preman (thugs) and black-clad "ninjas" (also called buffo, or clowns, in Tetun) can be traced back to the 1980s, though there is no doubt that it intensified during the mid-1990s. This was a response to two related developments. On the one hand, the "opening" of the province in 1989 entailed an official policy of downplaying the use of combat troops and emphasizing "territorial" functions. The result of this was that combat personnel were replaced by more covert (though no less deadly) perpetrators of violence. Furthermore, as a new generation of urbanized Timorese youths educated under Indonesian rule came of age, resistance to Indonesian rule shifted from the armed struggle in the mountains to urban protest in Dili. ${ }^{57}$ It was precisely during this period (1995-1996) that Timor was rocked by a series of localized riots and other disturbances. What conventional troops could not address, Kopassus (and its Timorese thugs) could combat through escalating violence and brutalization.

In sum, between early 1992 and 1996, a period of only four years, military control over East Timor was steadily but secretly transferred from Kolakops (based in Timor itself) to Kostrad brigades (based outside of East Timor) and then again to Kopassus (in particular Group III, based in Batujajar, West Java). This, as we will see, was to have enormous implications not only for the people of East Timor, but for militarization in Indonesia as well.

\section{The Timor Connection}

It remains to sketch briefly the links between these transformations of the Timor military command and the escalating use of violence by the state in Indonesia. For the sake of simplicity, we can focus on three areas: the behavior of troops returned from Timor, the use of preman in political affairs in Indonesia, and the events of early 1998 that culminated in Soeharto's fall from power.

First, troops involved in covert operations in Timor have, on their return to their base areas, used similar methods in Indonesia. The Indonesian military is clearly aware that illegal violence is something to which soldiers and officers alike becomes

\footnotetext{
54 "Brigif 15 Kujang diaktifkan kembali sebagai Satuan Pemukul Siliwangi," Angkatan Bersenjata, October $31,1994$.

55 See "Brigif 15 Kujang diaktifkan kembali sebagai Satuan Pemukul Siliwangi," Angkatan Bersenjata, July 4, 1997 and Suara Timor Timur, June 27, 1997.

56 On Prabowo and the establishment of paramilitary groups in East Timor, see "Crack in the Wall," Far Eastern Economic Review, September 3, 1998.

57 Benedict R. O'G. Anderson, "East Timor and Indonesia: Some Implications," in Carey, East Timor at the Crossroads, pp. 145-6.
} 
accustomed, and that those who use violence in one context are likely to resort to similar responses in other contexts. It is, therefore, common for commanding officers to caution troops returning from service in Timor to adjust their behavior accordingly. In January 1993, for example, the commander of Kodam V Brawijaya (East Java) warned Infantry Battalion 511, which had just completed thirteen months service in Timor, "to leave behind those habits from duty in an operations area that don't fit with conditions here [in East Java]," and "to avoid being arrogant, conceited and always think that they are right because they just returned home from an operations area." 58 Despite these warnings, it is in fact quite common for troops recently returned from Timor to be involved in the use of violence against civilians in Indonesia.

A second feature of the mass violence in Indonesia during the mid-1990s is the role played by preman - thugs and hooligans-in infiltrating and disrupting peaceful social protest. ${ }^{59}$ In much the same way that ninja and buffo were initially organized and trained for operations in East Timor in response to the tactical shift from guerrilla warfare to urban protest, during the mid-1990s members of the military elite employed similar tactics with increasing frequency against the rising tide of civilian protest in Indonesia itself. The use of local "hooligans" in the ill-fated July 1996 attack on the headquarters of the Indonesian Democratic Party was only the most prominent and most violent of a growing trend. ${ }^{60}$ Other times, the connection between the East Timor command and violence was even more direct, as was the case when Timorese preman were used against Timorese dissidents during the 1994 APEC (Asia-Pacific Economic Cooperation) conference in the capital. Although certainly not new to the New Order, one significant lineage of using preman as an administrative method against civilian protest during the 1990s can be traced (at least in part) to the Timor campaign and the coterie of officers who rose to prominence there.

The role of Timorese and Timor-connected preman was not purely instrumental, of course. As already noted, ninja and buffo, operating under the guidance of the military, played a central role in creating a climate of terror in East Timor from the late 1980s on. By the mid-1990s many of these preman began to appear in the major cities of Java in increasing numbers, often brought to Java by their military handlers. Timorese preman quickly carved out niches for themselves in the urban underworld of rackets and extortion, often coming into direct conflict with other para-criminal groups. It is this dynamic that lay behind the the highly publicized gang violence involving the notorious Hercules in Jakarta in 1997 and early 1998.61

Finally, we come to the spiraling sequence of events during the first half of 1998 that culminated in Soeharto's forced resignation. These, of course, bear the prints of their origins. First, the cast of characters remains all too familiar-Prabowo Subianto,

58 "Yonif 511 selesai Operasi Teritorial di daerah Timor Timur," Angkatan Bersenjata, January 13, 1993. The first part of the statement reads: ". . . tinggalkan kebiasaan dalam pelaksanaan tugas daerah operasi yang tidak cocok dengan keadaan di sini ...."

59 On preman, see the excellent essay by Loren Ryter, "Pemuda Pancasila: the Last Loyalist Free Men of Soeharto's Order?" Indonesia 66 (October 1998): 45-74.

${ }^{60}$ For a full account, see Gerakan Pro Demokrasi Digebuk: Tentang Peristiwa 27 Juli 1996 (Human Rights Watch/Asia and Robert F. Kennedy Memorial for Human Rights, 1996).

${ }^{61} \mathrm{See}$, for example, the description and chronology in "Tergusurnya Eksistensi Orang Timtim dari Jakarta," posted on <SiaR@mole.gn.apc.org $>$. 
Sjafrie Syamsudin, Moch. Irianto, Gerhan Lentara, and friends. The respective positions of these officers during the 1990s are traced in Figure 1. Second, in early 1998, as student demonstrations gripped campuses across Java, Sumatra, and Sulawesi, student and NGO activists began to disappear. While kidnappings and disappearances have not been a standard part of military procedure in Indonesia under Soeharto, they are commonplace in the operation areas of East Timor, Aceh, and Irian Jaya. Third, the organized use of rape against civilians during the May riots is a means of terror that has employed commonly in the Timor and Aceh campaigns. ${ }^{62}$

This is not to suggest that Prabowo and his colleagues had (or needed) widespread support within the military. The instigation of riots, kidnappings, and even coordinated mass rape require intense organization and resources, but not general agreement or cooperation among the officer corps. Indeed, the swift transfer of Lieut. Gen. Prabowo from his command of Kostrad to head the Armed Forces Staff and Command School in Bandung on May 22, 1998, and his subsequent dismissal from the military several months later, the reappointment of Major Gen. Sjafrie from his strategic post as commander of Kodam Jaya (Jakarta) to an administrative post in July, 1998, and the large-scale personnel reshuffle in early 1999 all occurred without protest or even the slightest sign of resistance from the officer corps, attesting to the general lack of support for this cowboy clique.

While a full account of Kopassus activities may never be made public, the pattern of violence and the personnel involved in early 1998 mirror those found in Dili seven years before. We might conclude by returning to the Jakarta Post editorial with which we began. It continues:

ABRI must stop treating dissenting civilians like enemies in a war. And it must do so without delay, or not only will ABRI lose all credibility, the country and the nation will be placed in danger of disintegration. It is no coincidence that separatist movements are strong - and have managed to remain strong-in the so-called military operations zones of Aceh, East Timor and Irian Jaya. ${ }^{63}$

Indeed, repression appears to be one essential ingredient in fueling movements of resistance. Benedict Anderson has argued that it was the combination of development, education, and repression that gave birth to the Indonesian movement for independence and, ironically, resistance in Timor as well. ${ }^{64}$ A similar constellationdevelopment and economic collapse, education and exclusion, and the crudest forms of repression--produced the wave of popular protest that ended Soeharto's rule. For this, Indonesia has East Timor to thank.

\footnotetext{
62 This is well-documented by George J. Aditiondro in "Violence by the State Against Women in East Timor," posted on Senirupa@jakarta.wasantara,net.id>, August 3, 1998.

63 "The Aceh Killing Fields," Jakarta Post, August 6, 1998.

64 Benedict Anderson, "Gravel in Jakarta's Shoes," in The Spectre of Comparisons: Nationalism, Southeast Asia and the World (London: Verso, 1998), p. 134.
} 